\section{Zonal Geranium Growth and Flowering Responses to Six Growth Regulators}

\author{
Harry K. Tayama and Stephen A. Carver ${ }^{2}$ \\ Department of Horticulture, The Ohio State University, 2001 Fyffe \\ Court, Columbus, OH 43210
}

Additional index words. Pelargonium hortorurn, ethephon, chlormequat, daminozide, paclobutrazol, triapenthenol, uniconazole

\begin{abstract}
Two experiments were conducted to compare the efficacy of uniconazole (10-ppm spray and drench), paclobutrazol (15-ppm spray and drench), triapenthenol (132-ppm spray and drench), chlormequat (1500-ppm spray only), ethephon (500-ppm spray only $)$, and chlormequat + daminozide $(2500+1500 \mathrm{ppm}$ spray only $)$ combination for controlling stem elongation of zonal (cutting) geraniums [Pelargonium hortorum (L.H. Bailey)]. Additionally, the effect of these materials on days to anthesis, inflorescence number, and phytotoxicity was evaluated. Spray applications provided effective height control and did not affect days to anthesis or inflorescence number. Drench applications severely restricted growth and reduced inflorescence number, but did not delay flowering. None of the treatments was phytotoxic. Chemical names used: $\beta-[(4-$ chlorophenyl)methyl] - $\alpha$-(1,1-dimethylethyl)-1H-1,2,4-triazole-1-ethanol (paclobutrazol); 2 chloro-N,N,N-trimethylethanaminium chloride (chlormequat); $\alpha$-cyclopropyl- $\alpha$-(4-methoxyphenyl)-5-pyrimidinemethanol (ancymidol); (2-chloroethyl) phosphoric acid (ethephon); butanedioic acid mono(2,2-dimethylhydrazide) (daminozide); $\beta$-(cyclohexylmethylene)- $\alpha$-( 1,1-dimethylethyl) -1H-1,2,4-triazole-1-ethanol (triapenthenol); $(E)$ 1-(p-chlorophenyl) -4,4 -diemethyl 1-2(1,2,4-triazol-2-yl)-1-penten-3-o1 (uniconazole).
\end{abstract}

The zonal (cutting) geranium perennially ranks among the top five greenhouse flowering potted plants in total production units and wholesale value in the United States. Plant growth regulators are used to produce more-compact, attractive, and salable geraniums. Plant growth regulators most often recommended and used on these plants are chlormequat and ethephon. In addition to controlling stem elongation, ethephon promotes lateral branching, encouraging denser plant growth (Carpenter and Carlson, 1970; Semeniuk and Taylor, 1970; Tayama and Zrebiec, 1987), while chlormequat is reported to hasten anthesis of seed-propagated geraniums (Miranda and Carlson, 1980; Quatchak et al., 1986; White and Warrington, 1984). Problems have been noted with both materials. Ethephon causes flower bud

Received for publication 3 Mar. 1989. Salaries and research support provided by state and federal funds appropriated to The Ohio State Univ.. Ohio Agricultural Research and Development Center. Manuscript no. 39-89. We gratefully acknowledge the Ulery Greenhouse Co. for the donation of the zonal geraniums and W.R. Grace Co. for the donation of the Metro Mix 350. Trade names are used in this publication to provide specific information. Mention of a trade name does not constitute a guarantee of the product or an endorsement by The Ohio State Univ. over other products not mentioned. The cost of publishing this paper was defrayed in part by the payment of page charges. Under postal regulations, this paper therefore mus be hereby marked advertisement solely to indicate this fact.

'Professor.

${ }^{2}$ Senior Laboratory Demonstrator. abortion and a delay of subsequent flowering for up to 4 to 6 weeks following an application (Carpenter and Carlson, 1970; Semeniuk and Taylor, 1970; Reed, 1975; Tayama and Zrebiec, 1987). While this delay is a benefit when applied to stock plants, it may be a problem on finished plants. Chlormequat can cause chlorosis of the margins when used at recommended concentrations (Carlson and Kaczperski, 1987; Tayama and Zrebiec, 1987).

Some highly effective plant growth regulators have been developed in the past 8 to 10 years. Some of the new triazole materials are effective at much lower concentrations than established materials such as chlormequat or daminozide. Research is continuing to identify chemical concentrations and to develop schedules that will provide the desired control of stem elongation without causing problems such as restriction of lateral branching, reduction in flower number or size, delay of anthesis, or phytotoxicity. Paclobutrazol, a new triazole growth regulator, is currently labeled for use on various plants, including geraniums. Another, uniconazole, which is to be labeled shortly, also has demonstrated activity on a wide range of floricultural crops. A third, triapenthenol, has also been shown to be a very effective plant growth regulator, but, the Mobay Chemical Co. recently has identified some safety concerns with this material and will not be pursuing a label.

The purpose of these studies was to compare the efficacy of uniconazole, paclobutrazol, triapenthenol, chlormequat, ethephon, and a chlormequat + daminozide combi- nation for controlling stem elongation of zonal geraniums. Additionally, the effect of these materials on days to anthesis, inflorescence number, and phytotoxicity was evaluated.

On 12 Feb. 1988,200 'Yours Truly' zonal geraniums growing in a 90 peatmoss : 10 styrofoam medium in 0.5 -liter pots were recieved and placed on a $23 \times 23-\mathrm{cm}$ spacing. They were pinched to three nodes on 16 Feb. Plants were irrigated manually, as required, with a solution containing $200 \mathrm{ppm}$ each of $\mathrm{N}$ and $\mathrm{K}$ from Peter's 20N-4.3P-16.6K (W.R. Grace and Co., Fogelsville, Pa.). The geraniums were maintained at $15.5 \mathrm{C}$ nights and 15.5 to $21 \mathrm{C}$ days in an unshaded glasshouse. Inflorescences were regularly removed until the date of the last growth regulator treatment. Senescing leaves were continuously removed until the conclusion of the trial. The first treatment was applied when $4 \mathrm{~cm}$ of new stem had grown after pinching on 18 Mar. The second treatment was 15 days later. The study was concluded and data collected (except for days to flower) on 21 Apr.

A second experiment was initiated 19 May 1988. Two-hundred rooted cuttings of 'Yours Truly' were planted in 0.5-liter pots filled with Metro Mix 350 (W.R. Grace \& Co. ) and were topdressed with $2.4 \mathrm{~g}$ of Osmocote 19N-2.6P-9.9K (Sierra Chemical Co., Milpitas, Calif.). They were irrigated manually, as required, with a solution containing 200 ppm each of $\mathrm{N}$ and $\mathrm{K}$ from Peter's $20 \mathrm{~N}$ $4.3 \mathrm{P}-16.6 \mathrm{~K}$. The geraniums were maintained at $15.5 \mathrm{C}$ nights and 15.5 to $21 \mathrm{C}$ days in a shaded glasshouse. Unlike the plants in the first study, these geraniums were not pinched. Inflorescences were regularly removed until the date of the last growth regulator treatment. Senescing leaves were continuously removed until the conclusion of the trial. The first treatment was applied when $4 \mathrm{~cm}$ of new stem had grown after planting on 3 June. The second treatment was applied 17 days later. The study was concluded and data collected (except for days to flower) on 20 July.

In both experiments, 10 treatments were established in a randomized block design with three replicates per treatment and six plants per replication. The spray treatments were applied at a concentration of 3.8 liters of plant growth regulator solution per $18.6 \mathrm{~m}^{2}$ of bench space or $2.0 \mathrm{ml}$ per plant (calculated on the basis of $10-\mathrm{cm}$ pots, $=0.5$ liter, spaced pot to pot, with the growth regulators sprayed uniformly over head). The drench application concentration was $59 \mathrm{ml}$ of solution per 0.5-liter pot. All treatments were applied twice. The treatments are listed in Table 1.

Response to the various treatments was recorded as plant height (from pot rim to the top leaf), plant diameter (measured in perpendicular directions), total inflorescences (including those that were at or had extended above the level of the foliage, but were not yet open), and days to flower. Days to flower was determined by averaging the number of days from the last application to the time the first plant in each of the three replications 
Table 1. Growth and flowering of 'Yours Truly' geranium in response to various chemical growth regulator treatments.

\begin{tabular}{|c|c|c|c|c|c|c|c|c|c|c|}
\hline \multicolumn{3}{|c|}{ Growth regulator } & \multicolumn{2}{|c|}{$\begin{array}{l}\text { Plant } \\
\text { ht }(\mathrm{cm})\end{array}$} & \multicolumn{2}{|c|}{$\begin{array}{c}\text { Plant } \\
\text { diam }(\mathrm{cm})\end{array}$} & \multicolumn{2}{|c|}{$\begin{array}{c}\text { Inflorescences } \\
\text { per plant }\end{array}$} & \multicolumn{2}{|c|}{$\begin{array}{l}\text { Days to } \\
\text { flower }\end{array}$} \\
\hline \multirow[b]{2}{*}{ Kind } & \multirow{2}{*}{$\begin{array}{l}\text { Concn } \\
\text { (pprn) }\end{array}$} & \multirow{2}{*}{$\begin{array}{l}\text { Application } \\
\text { method }\end{array}$} & \multicolumn{8}{|c|}{ Experiment } \\
\hline & & & 1 & 2 & 1 & 2 & 1 & 2 & 1 & 2 \\
\hline None (water) & & & $16.0 \mathrm{a}$ & $17.7 \mathrm{a}$ & $26.7 \mathrm{a}$ & $25.7 \mathrm{~b}$ & $3.3 \mathrm{ab}$ & $8.0 \mathrm{bc}$ & $13 a$ & $14 \mathrm{a}$ \\
\hline Ethephon & 500 & Spray & $14.3 \mathrm{bc}$ & $16.0 \mathrm{~b}$ & $26.0 \mathrm{ab}$ & $28.7 \mathrm{a}$ & $4.0 \mathrm{a}$ & $10.3 \mathrm{a}$ & $14 \mathrm{a}$ & $14 \mathrm{a}$ \\
\hline Chlormequat & 1500 & Spray & $13.3 \mathrm{c}$ & $14.7 \mathrm{bc}$ & $26.0 \mathrm{ab}$ & $22.7 \mathrm{bcd}$ & $3.7 \mathrm{a}$ & $8.3 \mathrm{bc}$ & $13 \mathrm{a}$ & $10 \mathrm{~b}$ \\
\hline Daminozide/chlormequat & $2500 / 1500$ & Spray & $15.3 \mathrm{ab}$ & $15.3 \mathrm{bc}$ & $25.7 \mathrm{ab}$ & $22.0 \mathrm{~cd}$ & $3.7 \mathrm{a}$ & $9.3 \mathrm{ab}$ & $14 \mathrm{a}$ & $14 \mathrm{a}$ \\
\hline Paclobutrazol & 15 & Drench & $10.7 \mathrm{~d}$ & $9.3 \mathrm{e}$ & $24.3 \mathrm{abc}$ & $14.3 \mathrm{e}$ & $2.3 \mathrm{c}$ & $7.3 \mathrm{c}$ & $15 \mathrm{a}$ & $14 \mathrm{a}$ \\
\hline & 15 & Spray & $15.0 \mathrm{ab}$ & $13.0 \mathrm{~d}$ & $25.7 \mathrm{ab}$ & $21.0 \mathrm{~d}$ & $3.7 \mathrm{a}$ & $9.3 \mathrm{ab}$ & $12 \mathrm{a}$ & $14 \mathrm{a}$ \\
\hline Triapenthenol & 132 & Drench & $11.0 \mathrm{~d}$ & $8.7 \mathrm{e}$ & $23.0 \mathrm{c}$ & $15.7 \mathrm{e}$ & $2.7 \mathrm{bc}$ & $7.3 \mathrm{c}$ & $13 \mathrm{a}$ & $9 \mathrm{~b}$ \\
\hline & & Spray & $15.0 \mathrm{ab}$ & $14.0 \mathrm{~cd}$ & $26.0 \mathrm{ab}$ & $24.7 b c$ & $3.3 \mathrm{ab}$ & $8.7 \mathrm{abc}$ & $14 \mathrm{a}$ & $14 \mathrm{a}$ \\
\hline Uniconazole & 10 & $\begin{array}{l}\text { Drench } \\
\text { Spray }\end{array}$ & $\begin{array}{l}11.3 \mathrm{~d} \\
14.0 \mathrm{bc}\end{array}$ & $\begin{array}{l}9.3 \mathrm{e} \\
15.3 \mathrm{bc}\end{array}$ & $\begin{array}{l}23.7 \mathrm{bc} \\
25.3 \mathrm{abc}\end{array}$ & $\begin{array}{l}15.0 \mathrm{e} \\
24.3 \mathrm{bc}\end{array}$ & $\begin{array}{l}2.3 \mathrm{c} \\
3.3 \mathrm{a}\end{array}$ & $\begin{array}{l}7.0 \mathrm{c} \\
8.7 \mathrm{abc}\end{array}$ & $\begin{array}{l}15 \mathrm{a} \\
14 \mathrm{a}\end{array}$ & $\begin{array}{r}9 \mathrm{~b} \\
14 \mathrm{a}\end{array}$ \\
\hline
\end{tabular}

${ }^{2}$ Mean separation by Duncan's multiple range test at the 5\% level.

within a treatment flowered. Data were collected 19 days after the last application in the first experiment and 31 days after the last application in the second experiment. An analysis of variance was performed.

Drenches with the three triazole growth regulators in both experiments produced excessive and unacceptable dwarfing of the leaves and petioles that developed after the first application. The marked effect of the drenches was not unexpected, since the amount of solution (and therefore the amount of active ingredient) applied to the plants as a drench was more than 25 times that applied, as a spray. Triazole drenches also reduced the number of inflorescences per plant. Also observed, but not specifically measured, was a dramatic dwarfing in the size of the inflorescences and peduncles. However, the time to flowering in these treatments was not delayed (Table 1).

The growth response to the spray applications varied slightly between the two experiments. This variation may be attributed to the difference in the interval between the date of the last application and the date of data collection. In the first study, only ethephon, chlormequat, and uniconazole, showed significant height reduction compared to the control treatment (Table 1). In the second experiment, all of the spray applications demonstrated efficacy, with paclobutrazol and triapenthenol plants showing the strongest response (Table 1). The spray applications had less of an effect on the width of the geraniums, with only uniconazole in the first experiment and paclobutrazol and triapenthenol in the second producing a significant effect over the control. Ethephon-treated plants in the second experiment were actually larger in diameter than the control. There was no evidence of phytotoxicity or abnormalities on the sprayed plants. In addition, there was no effect of the growth regulator spray applications on the number of inflorescences per plant, with the exception of the ethephon treatment in the second experiment. The ethephon-treated plants produced more inflorescences than the control plants, but not more than most of the other sprayed plants in the same experiment.

The results of the experiments demonstrated that all materials tested can be used effectively to control the growth of zonal geraniums. Ethephon, chlormequat, and uniconazole were consistently effective in both experiments.

Problems often associated with ethephon and chlormequat were not observed in these experiments. There was no evidence of leaf yellowing with chlormequat and no delay in flowering with ethephon treatments in either experiment. Chlormequat-treated plants were sprayed uniformly, but not to run-off, in an attempt to avoid phytotoxicity. The last observation of the ethephon-treated geraniums presents a conundrum. We observed the height control and increased branching obtained (not specifically evaluated, but implied by the increase in inflorescence number and plant diameter of the ethephon treated vs. the unpinched control plants in the second experiment), but not the delay in flowering typically associated with ethephon. Carpenter and Carlson (1970) and Semeniuk and Taylor (1970) have demonstrated a delay in flowering of seed geraniums following an application of ethephon. 'Larson (1988) and Tayama and Zrebiec (1987) state, and Reed (1975) demonstrated, that ethephon will cause a delay of flowering of zonal geraniums. The absence of flowering delay in our tests appears to be an anomaly.

\section{Literature Cited}

Carpenter, W.J. and W.H. Carlson. 1970. The influence of growth regulators and temperature on flowering of seed propagated geraniums. HortScience 5:183-184.

Carlson, W. and M . Kaczperski. 1987. Low cycocel rates effective on geraniums. Greenhouse Grower Mar. p. 12-13.

Miranda, R.M. and W.H. Carlson. 1980. Effect of timing and number of applications of chlormequat and ancymidol on the growth and flowering of seed geraniums. J. Amer. Soc. Hort. Sci. 105:273-277.

Quatchak, D. J., J.W. White, and E.J. Holcomb. 1986. Temperature, supplemental lighting, and chlonnequat chloride effects on flowering of geranium seedlings. J. Amer. Soc. Hort. Sci. 111(3):376-379.

Reed, D.D. 1975. Greenhouse studies on the effect of dusk to dawn low intensity lighting and florel on geranium stock plants. MS Thesis, The Ohio State Univ., Columbus.

Semeniuk, P. and R. Taylor. 1970. Effects of growth retardants on growth of geranium seedlings and flowering. HortScience 5:393-394.

Tayama, H.K. and V. Zrebiec. 1987. Growth regulator chart. Ohio Flor. Assn. Bul. 687:26,

White, F.W. and I.J. Warrington. 1984. Growth and development responses of geranium to temperature, light integral, CQand chlormequat. J. Amer. Soc. Hort. Sci. 109:728-735. 